\title{
Central hypocortisolism as part of combined pituitary hormone deficiency due to mutations of PROP-1 gene
}

\author{
C Asteria, J H A Oliveira ${ }^{1}$, J Abucham ${ }^{1}$ and P Beck-Peccoz \\ Institute of Endocrine Sciences, University of Milan, Ospedale Maggiore IRCCS, Milan, Italy and ${ }^{1}$ Department of Medicine, Universidad Federal de São \\ Paulo, São Paulo, Brazil
}

(Correspondence should be addressed to P Beck-Peccoz, Institute of Endocrine Sciences, Ospedale Maggiore IRCCS, University of Milan, Via F. Sforza, 35 20122-Milano, Italy; Email: paolo.beckpeccoz@galactica.it)

\begin{abstract}
Background: One of the causes of combined pituitary hormone deficiency (CPHD) is represented by Prophet of Pit-1 (PROP-1) gene inactivating mutations. This disorder is generally characterized by GH, $\mathrm{TSH}$, prolactin (PRL), and gonadotropin deficiency, but recent papers have described a concomitant alteration of the corticotrope function.

Objective: To make a detailed investigation of the hypothalamic-pituitary-adrenal axis in two sisters with PROP-1 gene mutations.

Patients: Two female siblings (17 and 16 years old) with CPHD, belonging to a Brazilian family of consanguineous parents, presented with growth retardation and central hypothyroidism during childhood, and showed central hypogonadism at the age of puberty. No clear clinical symptoms and signs of hypocortisolism were present.

Methods: GH, TSH, free thyroxine, total tri-iodothyronine, PRL, LH, FSH, ACTH and cortisol were measured in basal condition and after appropriate testing. The molecular study was performed by PCR amplification and sequencing analysis of PROP-1 gene.

Results: Both patients showed GH, PRL, LH and FSH deficiencies, associated with absent responses to an insulin tolerance test (ITT), TRH and GnRH injection. Circulating concentrations of TSH were normal in basal conditions, but failed to respond to a TRH test. Plasma ACTH concentrations were normal, but serum cortisol concentrations were below the lower limit of the normal range, showing a trend to decrease during 6 years of follow-up. The serum ACTH response to ITT was impaired, whereas its response to CRH was normal and prolonged. The cortisol response to both tests, and to the ACTH test, was clearly impaired. In both sisters, the genetic analysis showed the presence of a homozygous 2bp deletion (296delGA) of PROP-1 gene, which results in the synthesis of a protein with no residual functional activity.

Conclusion: In addition to GH, TSH, PRL and gonadotropin deficiency, patients with PROP-1 gene mutations can present with late-onset central hypocortisolism, possibly beause of the lack of important paracrine factors normally produced by the cells surrounding the corticotropes and absent in the pituitary of these patients, or because of progressive corticotrope apoptosis. This finding indicates the need for life-long endocrine monitoring of PROP-1-deficient patients.
\end{abstract}

European Journal of Endocrinology 143 347-352

\section{Introduction}

Combined pituitary hormone deficiency (CPHD) is a rare disorder that results from an impaired pituitary function of varied etiopathogenesis. CPHD is characterized by impaired production of growth hormone $(\mathrm{GH})$ and one or more of the other anterior pituitary hormones. In general this condition occurs sporadically and is mainly caused by organic lesions or damage secondary to breech delivery. However, familial occurrence of $\mathrm{CPHD}$ has been reported in several cases and it is characterized by autosomal recessive, autosomal dominant, or X-linked recessive inheritance. At present, two of the main pituitary transcription factors are implicated in the onset of this condition: the human homologue of the mouse Pit-1 (POU1F1) and the Prophet of Pit-1 (PROP-1). POU1F1 is a tissue-specific transcription factor $(1-4)$, expression of which is necessary for the determination and differentiation of somatotropes, lactotropes and caudomedial thyrotropes $(5,6)$. PROP-1 is a paired-like homeodomain protein expressed early in the pituitary gland. It is necessary for POU1F1 gene expression, for the differentiation of the POU1F1-dependent cell lineages, and for the differentiation of the gonadotropes $(7,8)$. As a consequence, in humans, dominant and recessive mutations in the 
POU1F1 gene cause CPHD with deficiency of GH, prolactin (PRL) and thyroid-stimulating hormone (TSH) (9-14). Affected patients show intact corticotropin and gonadotropin function, consistent with the presence of spontaneous puberty and fertility. In contrast, mutations of the PROP-1 gene are responsible for the absence of the Pit-1-dependent cell lineages and for reduced numbers of gonadotropes, which result in the deficiency of luteinizing hormone (LH) and follicle-stimulating hormone (FSH) in addition to GH, PRL and TSH (15-25).

Here, we report on two Brazilian sisters with CPHD caused by a homozygous mutation of the PROP-1 gene, thus confirming the importance of this transcription factor in the determination and function of multiple pituitary cell lineages. Moreover, we demonstrate that the clinical phenotype of CPHD caused by PROP-1 gene mutations also encompasses corticotrope deficiency, which may lead to central hypoadrenalism in later life.

\section{Participants}

Informed consent from each family member and approval by the Hospital Ethics Committee were obtained before the study.

The patients are two female siblings with CPHD, aged 17 years (patient 1 ) and 16 years (patient 2), belonging to a Brazilian family of consanguineous parents. A third sister, aged 18 years, and the parents are in good health, with height and weight within the normal range for the Brazilian population. No familial history of delayed puberty is present. The affected sisters were born at term after uneventful pregnancies. The delivery was by cesarean section in patient 1 and by spontaneous delivery in patient 2 . Birth weight and length were within normal standards. Neuromotor development was normal.

Growth retardation was noted by the mother when the older sister was 3 years old and the younger sister was 2years old. However, the patients were referred to the clinician only at the ages of 7 and 6 years respectively, when symptoms of hypothyroidism, such as constipation, cold intolerance and fatigue became apparent. At that time, GH, TSH and PRL deficiency were first diagnosed. Unfortunately, it was not possible to investigate the patients further and to establish the hormonal replacement therapy with recombinant human (rh) GH and L-thyroxine $\left(\mathrm{L}-\mathrm{T}_{4}\right)$ until the age of 11 and 10 years respectively, because of other serious problems in the family.

Before treatment with rhGH and $\mathrm{L}_{-} \mathrm{T}_{4}$, height-SD scores (H-SDS) measured at 11 years in patient 1 and 10 years in patient 2 , were $-6.0 \mathrm{H}$-SDS and -4.9 H-SDS respectively. After 5 years of hormonal replacement therapy, H-SDS improved to $-1.6 \mathrm{H}-\mathrm{SDS}$ and $-2.0 \mathrm{H}-\mathrm{SDS}$ respectively, with augmentation of growth velocity $(9.1 \pm 4$ and $9.0 \pm 3.3 \mathrm{~cm} /$ year during 5 years of follow-up respectively). Now, both patients are of normal stature compared with those of the parents $(152 \mathrm{~cm}$ in patient 1 and $149 \mathrm{~cm}$ in patient 2; mother's and father's heights: $151 \mathrm{~cm}$ and $168 \mathrm{~cm}$ respectively) and normal weight and body mass index (BMI) $(47.8$ and $45.7 \mathrm{~kg}$ and 20.8 and $20.6 \mathrm{~kg} / \mathrm{m}^{2}$ in patients 1 and 2 respectively). However, bone age remains delayed in both patients, being of about 13 years, probably because of the concomitant presence of central hypogonadism which is responsible for severe delayed puberty in both sisters; at the ages of 16 and 15 years respectively, they showed spontaneous breast stage Tanner II and pubic hair stage Tanner I. This condition required estrogens and progesterone replacement therapy. To date, no clear clinical symptoms and signs of central hypocortisolism are present. Magnetic resonance imaging of the skull showed normal pituitary size (4.8 and $5.1 \mathrm{~mm}$ in patient $1 \mathrm{~s}$ and 2, respectively compared with $5.2 \pm 0.7 \mathrm{~mm}$ of pituitary height in matched controls) and morphology, normal stalk and normally located posterior pituitary lobe.

All the biochemical examinations performed in the patients were carried out when they were 16 and 15 years old respectively. Before measurement of TSH, PRL, $\mathrm{LH}$ and FSH concentrations, the replacement therapy with rhGH, L-T 4 , estrogens and progesterone was discontinued for 2 months; GH, ACTH and cortisol were evaluated during the period of treatment.

\section{Methods}

\section{Biochemical studies}

Basal circulating concentrations of $\mathrm{GH}$, TSH, free thyroxine $\left(\mathrm{FT}_{4}\right)$, total tri-iodothyronine $\left(\mathrm{TT}_{3}\right)$, PRL, LH and FSH were measured by an immunofluorimetric (IFMA) assay, using AutoDelfia technology (Wallac, Turku, Finland). Plasma ACTH and serum cortisol levels were measured on unextracted samples by IRMA (Nichols Institute, San Juan Capistrano, CA, USA) and RIA (Diagnostic products, Los Angeles, CA, USA) respectively. The intra- and interassay coefficients of variation were $3.1-7.3 \%$ and $4.6-5.4 \%$, respectively. The lower limits of sensitivity were $0.45 \mathrm{pmol} / \mathrm{l}$ for plasma ACTH and $10 \mathrm{nmol} / \mathrm{l}$ for serum cortisol. Serum transcortin concentrations were evaluated by IRMA (Bouty, Cinisello-Balsamo, Italy).

The TSH and PRL responses to TRH (200 $\mu$ g i.v.), and the LH and FSH responses to GnRH (100 $\mu \mathrm{g}$ i.v.) were evaluated after withdrawal of $\mathrm{rhGH}, \mathrm{L}-\mathrm{T}_{4}$, estrogens and progesterone. In contrast, the cortisol response to ACTH $(250 \mu \mathrm{g}$ i.v. in a single administration and $250 \mu \mathrm{g}$ i.m. every $24 \mathrm{~h}$ for 3 days) and CRH ( $1 \mu \mathrm{g} / \mathrm{kg} \mathrm{i.v.),} \mathrm{and}$ the $\mathrm{GH}$, cortisol and ACTH responses to an insulin tolerance test (ITT: $0.15 \mathrm{U} / \mathrm{kg}$ i.v.) were evaluated during replacement therapy.

\section{Genetic analysis of the PROP-1 gene}

The genetic analysis was performed by extracting genomic DNA from peripheral blood lymphocytes 
Table 1 Serum TSH, PRL and gonadotropin concentrations in patients 1 ( 16 years old) and 2 (15 years old), in basal conditions and after stimulatory tests, as studied after 2 months of withdrawal of substitutive therapy.

\begin{tabular}{|c|c|c|c|c|c|}
\hline \multirow[b]{3}{*}{ Hormone } & \multirow[b]{3}{*}{ Patients or controls } & \multicolumn{4}{|c|}{ Test } \\
\hline & & \multicolumn{2}{|c|}{ TRH } & \multicolumn{2}{|c|}{ GnRH } \\
\hline & & Basal & Peak & Basal & Peak \\
\hline TSH $(\mathrm{mU} / \mathrm{l})$ & $\begin{array}{c}1 \\
2 \\
\text { controls }\end{array}$ & $\begin{array}{c}1.8 \\
2.6 \\
0.26-5\end{array}$ & $\begin{array}{l}0.7 \\
0.4 \\
\geq 6\end{array}$ & & \\
\hline $\mathrm{PRL}(\mathrm{mU} / \mathrm{l})$ & $\begin{array}{c}1 \\
2 \\
\text { controls }\end{array}$ & $\begin{array}{r}92 \\
120 \\
>125\end{array}$ & $\begin{aligned} & 92 \\
& 17 \\
\geq & 500\end{aligned}$ & & \\
\hline LH (U/I) & $\begin{array}{c}1 \\
2 \\
\text { controls } \dagger\end{array}$ & & & $\begin{array}{l}0.2 \\
0.1 \\
>3\end{array}$ & $\begin{array}{c}0 \\
0.3 \\
>12\end{array}$ \\
\hline FSH (U/I) & $\begin{array}{c}1 \\
2 \\
\text { controls } \dagger\end{array}$ & & & $\begin{array}{l}0.2 \\
0.2 \\
>2\end{array}$ & $\begin{array}{r}0 \\
0 \\
>6\end{array}$ \\
\hline
\end{tabular}

† Controls $(n=63)$ were matched for sex and age.

using standard methods. The coding sequence of the PROP-1 gene was PCR-amplified with specific primers (sense prime: 5'-CGA ACA TTC AGA GAC AGA GTC CCA GA-3'; anti-sense primer: 5'-GAA TTC ACC ATG ATC TCC $\left(\mathrm{CA}^{\prime} 3^{\prime}\right)$ to generate a $3.5 \mathrm{~kb}$ fragment. The PCR reaction was performed using $500 \mathrm{mg}$ genomic DNA as template in a volume of $50 \mu \mathrm{l}$. The PCR cycles consisted of $30 \mathrm{~s}$ at $98^{\circ} \mathrm{C}$, followed by 30 cycles of $30 \mathrm{~s}$ at $94^{\circ} \mathrm{C}, 30 \mathrm{~s}$ at $56^{\circ} \mathrm{C}$ and $4 \mathrm{~min}$ at $68^{\circ} \mathrm{C}$. The PCR products were purified by gel electrophoresis followed by agarose gel DNA extraction. Direct sequencing of the double-stranded PCR fragments was performed by an automated method (PE Applied Biosystems, ABI PRISM 310 DNA Sequencer, Perkin-Elmer) using specific primers.

\section{Results}

\section{Biochemical features}

Both affected sisters exhibited GH, PRL, LH and FSH deficiencies, associated with absent response of these hormones to provocative stimuli (Tables 1 and 2). Circulating concentrations of TSH were normal in basal conditions, but failed to respond to TRH (Table 1). Without $\mathrm{L}_{-} \mathrm{T}_{4}$ replacement therapy, basal $\mathrm{FT}_{4}$ concentrations were below the normal range $(2.5$ and $3.9 \mathrm{pmol} / \mathrm{l}$ in patients 1 and 2 respectively; normal range $9-20 \mathrm{pmol} / \mathrm{l})$. During $\mathrm{L}_{-} \mathrm{T}_{4}$ treatment, circulating concentrations of $\mathrm{FT}_{4}$ and $\mathrm{TT}_{3}$ were in the normal range (FT4 15.2 and $15.7 \mathrm{pmol} / \mathrm{l}$ and TT3 1.5 and $1.7 \mathrm{nmol} / \mathrm{l}$ in patients 1 and 2 respectively; normal range $1.4-$ $2.9 \mathrm{nmol} / \mathrm{l}$ ). In basal conditions, circulating concentrations of ACTH were normal (Table 2), but serum cortisol concentrations were low in both sisters, showing a trend to decrease during 6 years of follow-up (Fig. 1). Serum transcortin concentrations were within the normal range $(648$ and $722 \mathrm{nmol} / \mathrm{l}$ in patients 1 and 2 respectively; normal range $620-740 \mathrm{nmol} / \mathrm{l}$ ).

The serum ACTH response to ITT was impaired, but its response to $\mathrm{CRH}$ was normal and prolonged, as the peak response was observed at $120 \mathrm{~min}$, whereas in normal subjects it occurs at $30 \mathrm{~min}$ (Table 2). The cortisol response to both tests (ITT and CRH), and to ACTH (250 $\mu \mathrm{g}$ i.v.) given in a single administration, was clearly impaired (Table 2). Nevertheless, a prolonged administration of ACTH $(250 \mu \mathrm{g}$ i.m. every $24 \mathrm{~h}$ for 3 days), performed at the patients' current ages of 17 and 16 years respectively, induced a normal cortisol increase in both of them (basal cortisol concentrations 66 and $71 \mathrm{nmol} / \mathrm{l}$ in patients 1 and 2 respectively; concentrations after $72 \mathrm{~h} 849$ and $825 \mathrm{nmol} / \mathrm{l}$ in patients 1 and 2 respectively; normal response $>600 \mathrm{nmol} / \mathrm{l}$ ).

Table 2 Serum cortisol, ACTH and GH concentrations in patients 1 (16 year old) and 2 (15 years old), in basal conditions and after stimulatory tests, during hormonal replacement therapy.

\begin{tabular}{|c|c|c|c|c|c|c|c|c|c|c|}
\hline \multirow[b]{3}{*}{ Hormone } & \multirow[b]{3}{*}{ Patient or controls $\dagger$} & \multicolumn{9}{|c|}{ Test } \\
\hline & & \multicolumn{3}{|c|}{ ITT } & \multicolumn{3}{|c|}{$\mathrm{CRH}$} & \multicolumn{3}{|c|}{ ACTH } \\
\hline & & Basal & Peak & $\Delta \ddagger$ & Basal & Peak & $\Delta$ & Basal & Peak & $\Delta$ \\
\hline Cortisol (nmol/l) & $\begin{array}{c}1 \\
2 \\
\text { controls }\end{array}$ & $\begin{array}{c}118 \\
314 \\
140-700\end{array}$ & $\begin{array}{r}237 \\
281 \\
\geq 500\end{array}$ & $\begin{array}{r}119 \\
0 \\
\geq 200\end{array}$ & $\begin{array}{c}118 \\
237 \\
140-700\end{array}$ & $\begin{array}{r}278 \\
287 \\
\geq 550\end{array}$ & $\begin{array}{r}160 \\
50 \\
\geq 200\end{array}$ & $\begin{array}{c}107 \\
198 \\
140-700\end{array}$ & $\begin{array}{r}298 \\
356 \\
\geq 500\end{array}$ & $\begin{array}{r}191 \\
158 \\
\geq 200\end{array}$ \\
\hline ACTH (pmol/l) & $\begin{array}{c}1 \\
2 \\
\text { controls }\end{array}$ & $\begin{array}{c}5.7 \\
7.1 \\
0.7-13.2\end{array}$ & & $\begin{array}{c}6.3 \\
2.7 \\
\geq 22\end{array}$ & $\begin{array}{c}4.2 \\
5.1 \\
0.7-13.2\end{array}$ & & $\begin{array}{l}13.5 \S \\
15.3 \S \\
\geq 4.4\end{array}$ & & & \\
\hline $\mathrm{GH}(\mathrm{mU} / \mathrm{l})$ & $\begin{array}{c}1 \\
2 \\
\text { controls }\end{array}$ & $\begin{array}{l}0.2 \\
1.2 \\
<4\end{array}$ & & $\begin{array}{r}0 \\
0 \\
\geq 20\end{array}$ & & & & & & \\
\hline
\end{tabular}

† Controls $(n=56)$ were matched for sex and age.

$\ddagger \Delta$ refers to the difference between the peak response and the basal value.

$\S$ These values were obtained 120 min after $\mathrm{CRH}$ injection in the patients, and at 30 min after the injection in normal individuals. 


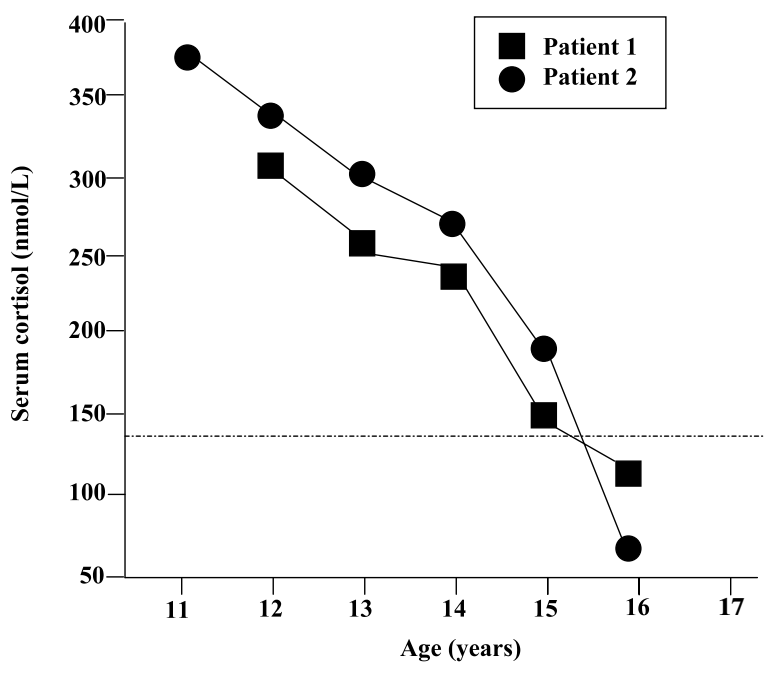

Figure 1 Basal serum cortisol concentrations evaluated during 5 years of follow-up in the two patients. Blood samples for cortisol measurements were collected at $0800-0900 \mathrm{~h}$. The horizontal dotted line represents the lowest limit of the normal range.

\section{Genetic studies}

Sequence analysis revealed in these affected sisters the presence of a homozygous 2-bp deletion at position 296 (296delGA) on exon 2 of the PROP-1 gene. This deletion results in a frame shift that leads to a transitional stop signal at codon 109 (S109X). The predicted protein is truncated at residue 108 and lacks part of the homeodomain, thus becoming unable to bind the promoter sites and to activate transcription of target genes (15). The parents and the third sister were heterozygous for this mutation.

\section{Discussion}

In this study, we described two Brazilian sisters affected with CPHD caused by PROP-1 deficiency. In both patients, in agreement with previously reported data (20), the initial clinical sign of the disease was growth retardation. Height velocity was dramatically slow during childhood. However, the diagnosis of CPHD was not made until the sisters were aged 7 and 6 years, when symptoms of TSH deficiency became evident. At that time also, PRL deficiency was detected. A few years later, hormonal replacement therapy with rhGH and $\mathrm{L}-\mathrm{T}_{4}$ was established, leading to normalization of the final height. Both sisters now present normal stature, weight and BMI, but delayed bone maturation is still present. This finding may also be related to the concomitant hypogonadotropic hypogonadism documented by severe delayed puberty and lack of gonadotropin response to GnRH. At ages 16 and 15 years, biochemical studies in both patients showed very low basal GH, PRL, LH and FSH concentrations and complete absence of response to specific releasing hormones. Without $\mathrm{L}-\mathrm{T}_{4}$ therapy, circulating concentrations of TSH at baseline were normal, but thyroid hormone concentrations were in the hypothyroid range, suggesting a central hypothyroidism resulting from the secretion of TSH molecules with reduced TSH bioactivity (26). Nevertheless, contrary to what is observed in central hypothyroidism of hypothalamic origin, which also may result in the secretion of bioinactive TSH, the TSH response to TRH was neither exaggerated or prolonged, but absent, in keeping with an impairment of thyrotrope development.

The most interesting finding of the present study relates to the adrenal function of our patients. It was observed that basal cortisol concentrations gradually declined over time and were clearly within the hypoadrenal range in both patients. In order to document the origin of such a hypocortisolism, an extensive biochemical analysis of the hypothalamicpituitary-adrenal axis was carried out by evaluating serum cortisol and ACTH concentrations in basal conditions and after several provocative tests. The results showed a central origin of the hypocortisolism. Indeed, in both patients, cortisol concentrations failed to respond to all the stimulatory tests applied (ITT, CRH and ACTH given in one bolus). Moreover, circulating concentrations of ACTH, normal in basal conditions, failed to respond to ITT and showed a prolonged response to CRH. To further confirm the normal function of the adrenal glands, ACTH was given to the patients every $24 \mathrm{~h}$ and cortisol was measured after 24 , 48 and $72 \mathrm{~h}$, showing a normal increase.

This condition of central hypocortisolism seems to be of late onset and becomes evident gradually over time. Similar results have been reported recently by Pernasetti et al. (25), who found a tendency to ACTH/ cortisol deficiency with age in six of 10 PROP-1deficient patients from Brazil. Moreover, these authors noted that ACTH and cortisol responses to ITT and CRH exhibited a negative correlation with age. It is tempting to speculate that the progressive hypocortisolism may be related to the lack of important paracrine factors normally produced by the cells surrounding the corticotropes, which are absent from the pituitaries of these patients. Alternatively, it could reflect corticotrope apoptosis occurring over time in PROP-1-deficient patients (25).

Despite the presence of an impaired adrenal function, neither of these affected sisters presented clear symptoms or signs of hypocortisolism. However, we decided to treat them with cortisol replacement therapy in order to prevent the life-threatening features of adrenal insufficiency that may become apparent in the event of severe physical and psychological conditions of stress.

Although we found a normal pituitary gland in both patients at the ages of 16 and 15 years respectively, changes in pituitary size and morphology can occur over time in PROP-1-deficient patients. Mendonca et al. 
(23) described one patient with PROP-1 deficiency who presented an enlarged and hyperintense pituitary gland at the age of 8.8 years and a hypoplastic anterior pituitary lobe 6 years later. Therefore, repeated imaging studies of the skull appear to be necessary in order to monitor the size of the pituitary in these patients.

Finally, genetic analysis showed a homozygous 2-bp deletion (296delGA) of the PROP-1 gene in both patients. The third sister and the parents were heterozygous, suggesting an autosomal recessive pattern of inheritance of the disease. This deletion, which has been referred to as 301-302delAG by some authors $(15,18,23-25)$, leads to a truncated protein at residue 108 that lacks the DNA-binding and the C-terminal trans-activation domains. Thus, when the 296delGA mutant is expressed in the context of mouse Prop-1, it lacks promoter binding and transcriptional activation activities (15). Until now, the same mutation has been noted in families of different origin, suggesting that it could represent a mutational 'hot spot' $(18,19)$. In fact, it is located in a sequence of three-GA repeats in exon 2 (296GAGAGAG) and it is a common opinion that repeat sequences show more susceptibility to mutations responsible for human diseases. Moreover, as functional studies have demonstrated that the 296delGA mutant has no residual functional activity, this mutation could account for a severe phenotype of CPHD, characterized by deficiency in all the anterior pituitary hormones. In fact, all the patients reported to date with PROP-1 deficiency and ACTH/cortisol impaired secretion, in addition to GH, TSH, PRL and gonadotropin deficiency, show the same genotype (i.e. 296delGA) (23-25). However, further studies are necessary to confirm this particular genotype/phenotype correlation.

In summary, the present study confirms that, in addition to GH, PRL, TSH and gonadotropin deficiency, patients with PROP-1 gene mutations can present with late-onset cortisol insufficiency, possibly because of the lack of important paracrine factors normally produced by the cells surrounding the corticotropes and absent in the pituitary of these patients, or because of progressive corticotrope apoptosis. This distinct phenotype, characterized by the impaired secretion of all the anterior pituitary hormones, could be associated with the 296delGA mutation of PROP-1 gene, as it represents a complete loss of function mutation. As the hypocortisolism seems to become more and more evident with advancing age in PROP-1-deficient patients, a complete endocrine evaluation and life-long monitoring of these patients are recommended in order to guarantee that they receive the potentially life-saving cortisol replacement therapy.

\section{Acknowledgements}

This study was partially supported by grants from Ospedale Maggiore IRCCS (Milan, Italy) and MURST No. 9806243848-003 (Rome, Italy).

\section{References}

1 Ingraham HA, Albert VR, Chen R, Crenshaw III EB, Elsholtz HP, Kapiloff MS et al. A family of POU-domain and Pit-1 tissue-transcription factors in pituitary and neuroendocrine development. Annual Review of Physiology 199052 773-791.

2 Rosenfeld MG. POU-domain transcription factors: powerful developmental regulators. Gene and Development 19915 897907.

3 Ruvkin G \& Finney M. Regulation of transcription and cell identity by POU-domain proteins. Cell 199164 475-478.

4 Wegner M, Drolet DW \& Rosenfeld MG. POU-domain proteins: structure and function of developmental regulators. Current Opinion in Cell Biology 19935 488-498.

5 Ingraham HA, Chen R, Mangalam HJ, Elsholtz HP, Flynn SE, Lin CR et al. A tissue-specific transcription factor containing a homeodomain specifies a pituitary phenotype. Cell $198850519-$ 529.

6 Li S, Crenshaw III EB, Rawson EJ, Simmons DM, Swanson LW \& Rosenfeld MG. Dwarf locus mutants lacking three pituitary cell types result from mutations in the POU-domain gene Pit-1. Nature $1990347528-533$.

7 Andersen B, Pearse II RV, Jenne K, Sornson M, Lin SC, Bartke A et al. The Ames dwarf gene is required for Pit-1 gene activation. Developmental Biology 1995172 495-503.

8 Sornson MW, Wu W, Dasen JS, Flynn SE, Norman DJ, O'Connell SM et al. Pituitary lineage determination by Prophet of Pit-1 homeodomain factor defective in Ames dwarfism. Nature $1996384327-333$.

9 Radovick S, Nations M, Du Y, Berg LA, Weintraub BD \& Wondisford FE. A mutation in the POU-homeodomain of Pit-1 responsible for combined pituitary hormone deficiency. Science $1992257115-118$.

10 Pfäffle RW, Di Mattia GE, Parks JS, Brown MR, Wit JM, Jansen M et al. Mutation of the POU-specific domain of Pit-1 and hypopituitarism without pituitary hypoplasia. Science 1992257 $1118-1121$.

11 Ohta K, Nobukuni Y, Mitsubuchi H, Fujimoto S, Matsuo N, Inagaki $\mathrm{H}$ et al. Mutations in the Pit-1 gene in children with combined pituitary hormone deficiency. Biochemical and Biophysical Research Communications 1992189 851-855.

12 Tatsumi K, Miyai K, Notomi T, Kaibe K, Amino N, Mizuno Y et al. Cretinism with combined hormone deficiency caused by a mutation in the PIT1 gene. Nature Genetics 19921 56-58.

13 Okamoto N, Wada Y, Ida S, Koga R, Ozono K, Chiyo H et al. Monoallelic expression of normal mRNA in the PIT1 mutation heterozygotes with normal phenotype and biallelic expression in the abnormal phenotype. Human Molecular Genetics 19943 $1565-1568$

14 Cohen LE, Wondisford FE, Salvatoni A, Maghnie M, BruckerDavis F, Weintraub BD et al. A 'hot spot' in the Pit-1 gene responsible for combined pituitary hormone deficiency: clinical and molecular correlates. Journal of Clinical Endocrinology and Metabolism 199580 679-684.

15 Wu W, Cogan JD, Pfäffle RW, Dasen JS, Frisch H, O'Connell SM et al. Mutations in PROP1 cause familial combined pituitary hormone deficiency. Nature Genetics 199818 147-149.

16 Fofanova OV, Takamura N, Kinoshita E, Parks JS, Brown MR, Peterkova VA et al. A mutational hot spot in the PROP-1 gene in Russian children with combined pituitary hormone deficiency. Pituitary 19981 45-49.

17 Fofanova O, Takamura N, Kinoshita E, Parks JS, Brown MR, Peterkova VA et al. Compound heterozygous deletion of the PROP1 gene in children with combined pituitary hormone deficiency Journal of Clinical Endocrinology and Metabolism 199883 26012604.

18 Cogan JD, Wu W, Phillips III JA, Arnhold IJP, Agapito A, Fofanova OV et al. The PROP1 2- base pair deletion is a common cause of combined pituitary hormone deficiency. Journal of Clinical Endocrinology and Metabolism 199883 3346-3349. 
19 Deladoëy J, Flück C, Büyükgebiz A, Kuhlmann BV, Eblé A, Hindmarsh PC et al. 'Hot spot' in the PROP1 gene responsible for combined pituitary hormone deficiency. Journal of Clinical Endocrinology and Metabolism 199984 1645-1650.

20 Flück C, Deladoëy J, Rutishauser K, Eblé A, Marti U, Wu W et al. Phenotypic variability in familial combined pituitary hormone deficiency caused by a PROP1 gene mutation resulting in the substitution of Arg $\rightarrow$ Cys at codon 120 (R120C). Journal of Clinical Endocrinology and Metabolism 199883 3727-3734.

21 Duquesnoy P, Roy A, Dastot F, Ghali I, Teinturier C, Netchine I et al. Human PROP-1: cloning, mapping, genomic structure. Mutations in familial combined pituitary hormone deficiency. FEBS Letters 1998437 216-220.

22 Rosenbloom AL, Almonte AS, Brown MR, Fisher DA, Baumbach L \& Parks JS. Clinical and biochemical phenotype of familial anterior hypopituitarism from mutation of the PROP1 gene. Journal of Clinical Endocrinology and Metabolism 199984 50-57.

23 Mendonca BB, Osorio MGF, Latronico AC, Estefan V, Su Sih Lo L \& Arnhold IJP. Longitudinal hormonal and pituitary imaging changes in two females with combined pituitary hormone deficiency due to deletion of A301, G302 in the PROP1 gene. Journal of Clinical Endocrinology and Metabolism 199984 942945.

24 Parks JS, Brown MR, Baumbach L, Sanchez JC, Stanley CA, Giannella-Neto D et al. Natural history and molecular mechanisms of hypopituitarism with large sella turcica. In Book of Abstracts of the 80th Annual Meeting of The Endocrine Society, June 24-27 1998, New Orleans. Abstract P3-409, p 471.

25 Pernasetti FM, Toledo SPA, Vasilyev VV, Hayashida CY, Cogan JD, Ferrari $\mathrm{C}$ et al. Impaired adrenocorticotropin-adrenal axis in combined pituitary hormone deficiency caused by a two-base pair deletion (301-302delAG) in the prophet of Pit-1 gene. Journal of Clinical Endocrinology and Metabolism 200085 390-397.

26 Beck-Peccoz P \& Persani L. Variable biological activity of thyroidstimulating hormone. European Journal of Endocrinology 1994131 331-340.

Received 1 February 2000

Accepted 17 May 2000 